UDC 798.2(450)

\title{
POLISH HORSE-RIDING SCHOOL
}

\author{
Zbigniew Wójcik ${ }^{1}$, Tomasz Boraczyński ${ }^{1}$, Michał Boraczyński ${ }^{2}$
}

${ }^{1}$ Uniwersytet Warmińsko-Mazurski, Poland, zbigniew-wojcik@o2.pl

${ }^{2}$ Department of Health Sciences, Olsztyn University College, Poland, michal.boraczynski@gmail.com

https://doi.org/10.29038/2220-7481-2020-02-53-57

\begin{abstract}
s
The aim of the research was to recreate the processes determining the development of the concept of the Polish horse riding school. In the implementation of the previously adopted scheme, there were used methods in the field of historical and pedagogical science. As a result of the query, a lot of the material was obtained at the Central Military Archives in Warsaw and the Sports Museum in Olsztyn. It should be emphasized that the use of horses in the Republic of Poland has centuries of tradition. Yet in the 18th century, Polish horse riding school dominated in Europe. However, due to the subsequent partitions and the loss of independence, there were no conditions for further improvement of the equestrian art system. The next opportunity did not appear until 1918, when Poles created the foundation of statehood. Therefore, shortly thereafter, three military horse riding schools were established for the needs of the reviving weapon. They were dominated by the old classical-manege system, cultivated by senior officers from the former Armed Forces of Austria-Hungary. The new trends were initiated in the ranks of cavalry due to soldiers who had previously served in the army of the Russian partitioner. The results of the carried out research enabled to formulate the conclusion that allows to state that the clash of views among the officers resulted in the development of the principles of the Polish horse riding school. It was a combination of the Italian system and extensive experience of the former manege school. It was developed by horse riding instructors at the Cavalry Training Center in Grudziądz. Thanks to that, Polish horsemanship in the inter-war period was included in the world leaders.
\end{abstract}

Key words: The Republic of Poland, traditions, cavalry, officers, system, horse riding.

Збігнев Войчик, Томаш Борачинський, Міхал Борачинський. Польская школа верхової їзди. Мета дослідження - відтворити процеси, що визначають розвиток концепції польської школи верхової їзди. Під час реалізації раніше прийнятої схеми застосовували методи в галузі історико-педагогічної науки. За результатами запиту багато матеріалів отримано в Центральному військовому архіві у Варшаві та в Музеї спорту в Ольштині. Потрібно підкреслити, що використання коней у Республіці Польща має багатовікову традицію. Ще у XVIII ст. в Свропі панувала польська школа верхової їзди. Однак через наступні розділи та втрату незалежності не було умов для подальшого вдосконалення системи кінного мистецтва. Наступна можливість з'явилася до 1918 р., коли поляки заклали фундамент державності. Тому незабаром після цього створено три військові школи верхової їзди для потреб відроджувальної зброї. У них панувала стара класична манежна система, яку культивували старші офіцери колишніх Збройних сил Австро-Угорщини. Нові тенденції започатковано в лавах кінноти завдяки солдатам, котрі раніше служили в армії російського партизана. Результати проведеного дослідження дали підставу сформулювати висновок, який сприяє констатації, що зіткнення поглядів серед офіцерів призвело до розробки принципів польської школи верхової їзди. Це стало поєднанням італійської системи й великим досвідом колишньої школи манежу. Він розроблений інструкторами 3 верхової їзди в навчальному центрі кавалерії в Грудзодзь. Завдяки цьому польське конярство в міжвоєнний період включено до світових лідерів.

Ключові слова: Республіка Польща, традиції, кіннота, офіцери, система, верхова їзда.

Збигнев Войчик, Томаш Борачинский, Михал Борачинский. Польская школа верховой езды. Цель исследования - воспроизвести процессы, определяющие развитие концепции польской школы верховой езды. При реализации ранее принятой схемы использовались методы в области историко-педагогической науки. По результатам запроса много материалов получено в Центральном военном архиве в Варшаве и в Музее спорта в Ольштыне. Следует подчеркнуть, что использование лошадей в Республике Польша имеет многовековую традицию. Еще в XVIII в. в Европе работала польская школа верховой езды. Однако через разделы и потерю независимости не было условий для дальнейшего совершенствования системы конного искусства. Следующая возможность появилась до 1918 г., когда поляки создали фундамент государственности. Поэтому вскоре после этого сформировались три военные школы верховой езды для нужд возрождения оружия. В них царила старая классическая манежная система, которую культивировали старшие офицеры бывших Вооруженных сил Австро-Венгрии. Новые тенденции начались в рядах конницы, благодаря солдатам, которые ранее служили в армии российского партизана. Результаты проведенного исследования позволили сформулировать вывод: столкновение взглядов среди офицеров привело к разработке принципов польской школы верховой езды. Это было сочетанием итальянской системы и большим опытом бывшей школы манежа. Он разработан инструкторами верховой езды в учебном центре кавалерии в Грудзодзе. Благодаря этому, польское коневодство в межвоенный период включено в мировые лидеры.

Ключевые слова: Республика Польша, традиции, конница, офицеры, система, верховая езда. 
Introduction. The horse riding incompetence was closely related to the history of wars. It was only during the Age of Enlightenment and initiated strong current of humanism that the organized horse breeding became more important. Italian humanists from the centers in Milan, Rome and Florence were the creators of new trends, which in a short time covered almost all of Europe. These concepts penetrated many environments. They were also reflected in the systemic development of equestrian art. Then the Federico Grisone horse riding academy of in Naples became famous due to its innovation. This aristocrat, the author of the Gli ordini di cavalcare treatise (1550), is regarded as the founder of manege school [18]. It was initiated in Italy in the 16th century. Its horse riding style was characterized by forked seat and rider's torso inclined rearwards. That is why F. Grisone was hailed as the precursor of modern horse riding and Italy, due to the fact that the first academy was established there, as the cradle of modern horse riding style. He educated a large galaxy of enthusiasts who then set up subsequent schools throughout Italy. In the spirit of humanistic currents, equestrian academies began to develop in many European countries. For example, in the First Republic of Poland, the promoter of Italian training idea was Krzysztof Monwid Dorohostajski, later the Voivode of Płock and the Grand Marshal of Lithuania [20]. Such a program has been preffered by existing to present day the Spanish Court Equestrian School in Vienna. The foundation for its existence was created in the second half of the 16th century by the Austrian Archduke Charles of Lipizza. Then the art of horse riding was being developed for several centuries and had many varieties.

An important turnaround in this area took place in the 18th century, when the French horseman Francois Robichon de la Guerniere reformed his earlier horse riding systems, first of all making changes in the method of seat. He presented his methods of working with horses and the principles of horse riding training in the work titled Ecole de Cawallerie (1730) [18]. He should also be attributed to horse riding rules of the classical-manege school. Its basics were even taught by the King of France Louis XV. In Guerniere's concept, there was a saddle similar to the present one, which then turned out to be a design for the later English model. The French Cavalry School in Saumur, founded in 1765, also developed its own variation of the classic manege school. Due to the fact that it was famous for its high level of training, it has become the Royal Cavalry School since 1825 [20]. Regarded as a preeminent school, it was distinguished by a varied training base. It consisted of five well-equipped indoor riding arenas, training track and forests in the close proximity used for off-road horse riding. Another equally known school was the Cavalry School in Hanover. Its main task - as in the cases described above - was to meet the army's demands for the preparation of qualified NCOs and officers cadres. During its functioning, German canons of equestrian art were developed. Like the French Academy, it was distinguished by a well-organized training base. In 1930, Claus Schenk von Stauffenberg graduated from the Hanover Academy, the progenitor of the unsuccessful assassination attempt on Adolf Hitler in the East Prussia headquarters near Rastenburg.

Other well-known horse riding schools on the European continent were: the Russian Cavalry School in St. Petersburg (1857) and the Austrian Militär Reitlehrer Institute in Vienna (1875). Finally, it is worth emphasising that many Polish officers, who were on duty in both armies, graduated them [18]. In all the horse riding schools that were discussed, the classical-manege system was dominant. The style existing in the past centuries was developed by the Englishman James Fillis at the turn of the 19th and 20th centuries. He bashfully introduced some elements of off-road horse riding to the training. He included a consistent concept in the book Principes de dressage et d'equitation (1890) that was published in Paris. As a wellknown horseman and reformer, he later educated Russian officers at the Cavalry School in St. Petersburg [10]. Captain Federico Caprilli made a certain revolution in the current horse riding training system at the threshold of the 20th century. Thanks to the fact, in 1906, an innovative horse riding system called natural was introduced in all Italian schools, which then spread throughout the continent [21].

Goals and Methods of Research. The aim of the initiated studies was the re-enactment of the processes determining formation of the concept of the Polish horse-riding school. Taking this into consideration, the study was based on the hypothesis that the beginnings of systemic horse-riding studies are associated with the formation of the Polish State foundations after the end of World War I. Therefore, the following research questions were formulated:

1. How did the Polish traditions of horse usage develop?

2. In which time period did horse-riding schools function in the army of the Second Republic of Poland?

3. Where and when were the rules of the Polish horse-riding school established?

In the research process, the methods in the following fields of science were applied:

a) historical (indirect, direct, comparative).

b) pedagogical (analysis of documents). 
Equestrian Traditions. From the time of Mieszko I, knighthood of Polish kings, through all types of cavalry, national uprisings, until the time of World War I, the horse was the only possible way for the rapid movement of troops. The spectacular victories of the Polish armed forces have repeatedly determined the fate of the country and indicated the ability of the horse usage on the battlefield. In the 17th century, cavalry still prevailed in the Polish army, although efforts were made to keep infantry at 1:1 ratio [15]. The equestrian art expert and French stylist Victor Cherbulier expressed the view that two factors have the leading impact on the horse-riding system, i.e. broadly understood culture and principles of moral education within a period of time. In the history of the Republic of Poland, the mentioned criteria is particularly noticeable and equally important because in the 16th and 18th centuries Polish horsemanship dominated in Europe. The horse in the history of Poland played a significant role and the nobility worshiped it and could not get along without it because the horse served not only in the army but was also a show horse [15]. It fulfilled an important role in various types of ceremonies, while creating national customs at the same time. For example, rituals related to the coronation of kings were particularly important in Polish tradition. In addition, the horse was present in joyful moments, such as weddings, games or sleigh rides, and in sad ones like funerals. It was also seen as an evidence of wealthines ${ }^{1}$.

All things considered, it was given special affection, which also found its place in Polish literature, sculpture and painting.

Being attacked by foreign powers, the Republic of Poland developed a significant value system in defense of its statehood. The system was characterized by deep patriotism, courage and honor and particularly it found its reflection, inter alia in the ranks of the Polish cavalry, among others. Thus, the phenomenon of horse-riding in Poland has had centuries-old tradition, which in the armed forces manifested itself in the field of military horse-riding. Similarly, this phenomenon is defined by, among others Renata Urban [18].

The Trailers of Horsemanship System. The fall of the Commonwealth of Poland and Lithuania, the period of partitions and the lack of own army resulted in the fact that it was impossible to develop Polish horse-riding system. Such an opportunity did not appear until 1914, when the Poles saw the source of war struggle as a chance to regain independence. The germ of the national cavalry was «Lancer's Seven», (Belina's Seven), which by the order of Commander Józef Piłsudski, crossed the border cordon of the Russian partition at night on August 1st, 2nd, 1914 in order to explore the area and carry out propaganda action against the mobilization of Polish reservists $[5 ; 7 ; 16]$.

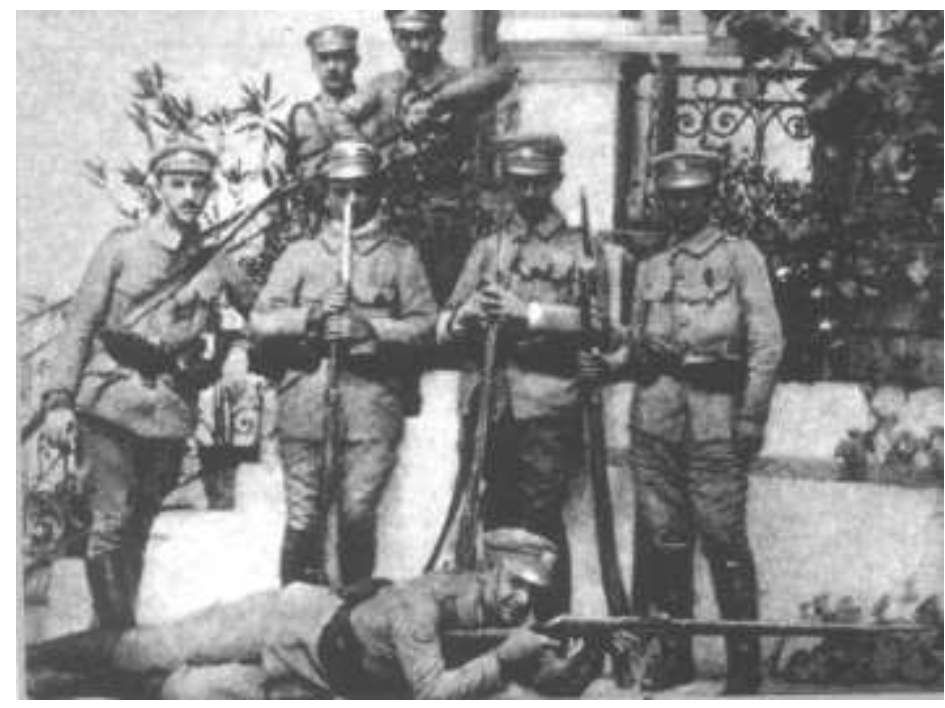

Photo 1. The Germ of the Cavalry of the Second Republic of Poland. On the Stairs from the Left: Ludwik Skrzyński «Kmicic», Władystaw Prażmowski «Belina». Below from the Left: Zygmunt Karwacki «Bończa», Stanisław Skotnicki «Grzmot», Janusz Gtuchowski «Janusz», Antoni Jabłoński «Zdzisław». In the Supine Position: Stefan Kulesza «Hanka». Goszyce 4. VIII. 1914. Source: P. Hubiak, Belina and his lancers. Kraków, 2003. P. 20.

${ }^{1}$ The fact of owning a horse confirmed, inter alia specific social position. Its special indications were, for example, Polish legations sent abroad. The one that came for Henry Valoisius delighted France with the multitude of horses and the richness of their appurtenance. The deputies entered the ceremonial entry into Paris through the St. Martin Gate in the 50th four-horse carriages. Then, they rode horseback and their saddles were framed in gold, their bridles gleamed with precious stones, their reins were studded with silver. (See Diplomats of former times. Old Polish accounts from the 16th and 17th centuries/ed. A. Przyboś, R. Żelewski. Kraków 1959. P. 106-107). 
The First Cadre Company soon entering this area removed the Russian border posts and gaining military experience, aimed to transform into a division of the Polish Legions. It should be emphasized that countrymen who had previously served in the partitioning armies also reported to the hastily formed military forces. It was for the needs of the reviving regular army in the autumn of 1919 that the first horse-riding schools were organized in Tarnów, Przemyśl and Stara Wieś. Well-known horsemen who recruited from the former army of the Austrian partitioner served as instructors. For this reason - although there were already disputes - the old manege system prevailed in the training until 1924. It is worth mentioning that it was developed in the 18th century by Francis Robichon de la Guèrinière, a horse-riding teacher of the King of France Louis XV. Basically, it came down to a change in horse-riding technique. On the other hand, ridden horse according to the principles propagated by Guèrinière, maintained an artificially formed silhouette and an unnatural balance imposed by the rider in all gaits and movements [18]. However, at the time while Poland was consolidating its independence with great effort and toil, the innovative system of the Italian officer Federico Caprilli had already been known on the European continent. Meanwhile, in the abovementioned military schools, the basics of horse-riding were taught in the old system. In Tarnów, training was provided by Col. Aleksander Żakiej and Capt. Jan Kossak, in Przemyśl Col. Franciszek Adamovich and Capt. Stefan Dębiński, while Capt. Władysław Bzowski with Capt. Ryszard Wolf Gierzkowski in Stara Wieś $[10,18]$. In the emerging formations, there was a lack of command and instructional staff, accordingly only the basics of equestrian art were taught, and their graduates were almost immediately directed to the forming regiments. These schools functioned very shortly. By the order of the Minister of Military Affairs of August 15th, 1920, they were combined into one Central Equestrian School with the headquarters in Grudziądz. The duties of the commander were entrusted to Colonel (later Brigadier General) to Stefan Kasprzycki, while Colonel A. Żakiej became the head of the equestrian training [2]. At that time, the horsemanship strengthened its position so that the sports horse-riding system was the basis for training of all horse troops in the Polish Army. This contributed significantly to the creation of a specific Polish horse-riding style. Its foundations came to the reborn Republic of Poland together with Polish officers who had previously served in the army of the Russian Tzar and who had already encountered the natural system developed in Italy. It differed from the manege school in that the rider left his partner a free, natural silhouette and adapted to horse movements. Horse-riding talents of, among others, Karol Rómmel, Sergiusz Zahorski and Leon Kon led to a clash of views with the existing followers of the manege-classical school represented by Polish officers of the Austrian army. This group was formed, among others, by Franciszek Adamovich, Hubert Brabec and Jan Kossak. The skilfully developed compromise between the representatives of two different schools was revealed in the joint development of new instructions by Kossak and Kon [17]. They embraced the basic principles of the Polish horse-riding system, which in general was characterized by a combination of the Italian system while maintaining the rich experience of the classical manege school and modified horse-riding. The effect of the Polish concept and its relevance were the numerous successes of our riders during the interwar period on the international arena ${ }^{2}$.

The expert on equestrian sport of that time, Lieutenant Grzegorz Romaszkan wrote in 1923: «Now we have our own Polish horse-riding school, which is still in the state of origin, but it has already managed to gain full confidence abroad» [14]. Another Pole, a triumphant of many European hippodromes, Captain Adam Królikiewicz, wrote in a similar tone: «... the Polish horse-riding school shaped its own direction» [6]. It was created by officers - horse-riding instructors at the Cavalry Training Center (hereinafter CWK) in Grudziądz. Over the years, they have been systematically improving it, and they passed their knowledge on this subject to the subsequent graduating classes at Grudziądz university. Królikiewicz and many other officers considered the Polish style to be different from the Italian system. The native horse-riding school was also noticeable in Europe. German hippologist Gustaw Rau, seeing Polish competitors at the Olympic Games in Amsterdam (1928), wrote about the riders of the Second Republic o Poland: «Poles were absolutely first-rate. And they adopted the Italian way, but they have many individual advantages, as well as the compelling flexibility and the ability to adapt to the horse in all situations. Their horses are not equal in breed. However, they have all one style at a gallop and jump. Such a team performance can only be the result of a long-term special elaboration» [12]. For above reasons, since 1929 many foreign officers have been

\footnotetext{
${ }^{2}$ The major achievements of Polish riders of this period include, among others, 4 Olympic medals: (Paris) $1924-$ bronze, individual jumping; Amsterdam 1928 - silver, team jumping and bronze in the International Eventing Competition, team jumping; Berlin 1936 - silver in the International Eventing Competition, as a team). With their successes they glorified the reviving Republic of Poland.
} 
educated in Grudziądz [10], and Polish contenders have achieved many successes in competing with riders not only from Europe. The afermath of this were the Olympic medals and eighteen times triumph in the Cup of Nations. Thus, the significant role of the horse was also visible in the national history on the sports level, and horse-riding contributed to a rich dower of the independent Republic of Poland. The Polish horse-riding school was strengthened by the decisions of the Ministry of Military Affairs and the Polish Equestrian Association (PZJ). In 1923, horse-riding competitions for the Polish Army Championships (Militari) were already introduced in the country and since 1931 also the Polish Equestrian Championships that included in their schedule competitions requiring preparation of the former manege school as well as the natural sytem $^{3}$.

The officers of the existing cavalry regiments and horse artillery squadrons took these contests very seriously, which was reflected in careful preparations in the indigenous units and existing schools, i.e. the CWK in Grudziądz and the Artillery Training Center (hereinafter CWA) in Torun [8]. In CWK, in March 1936, a permanent Equestrian Preparatory Group was established, headed by Major Kazimierz Szosland. As an assistant, he was assigned to Capt. Jan Mickunas (he descended from horse artillery) and Capt. Bolesław Pieczyński. Researching the issues of the equestrian dispute in the interwar period, Renata Urban reports that in 1939 the preparatory group owned 100 sport horses. This solution, due to the continuity of training, was very beneficial. In the previous years, national teams were created extemporaneously, before major competitions. The national team appointed the best officers from among all units of Polish Army.

It should be noted that the CWA was considered to be the second equestrian training center after Grudziądz. The foundation for its formation was the Central Camp for Artillery NCOs, established in February 1920 of artillery schools functioning in the territory of the Republic of Poland. The new organizational form facilitated management, but also the implementation of homogeneous concept of personnel training [3]. Horsesledging courses were also run at CWA, which was a significant trump. The Polish horse-riding school differed significantly from the system developed by Caprilli in the Italian cavalry school in Pinerolo in care for proper dressage, greater activity of riders in influencing horses, which ultimately gave Polish riders greater freedom in controlling the animal. In addition, Poles were characterized by a homogeneous mount and style of leading horses, described by many contemporary experts as elegant.

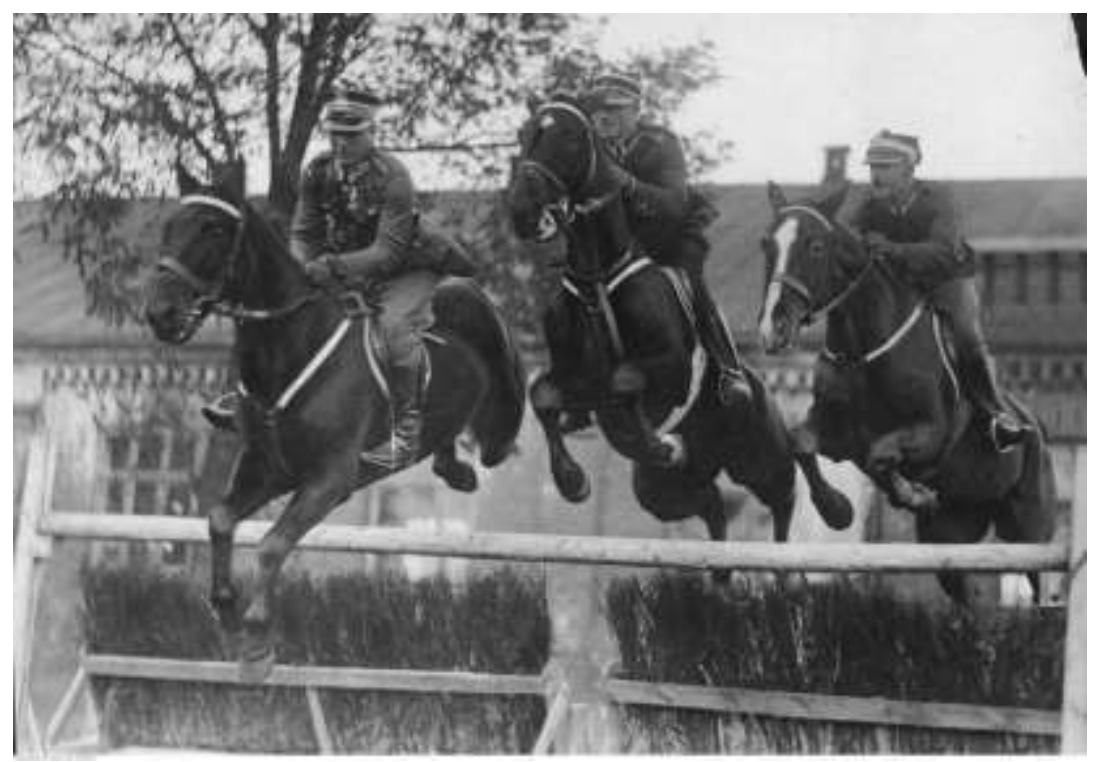

Photo 2. Riders - Graduates of the Polish Horse-Riding School - at a Competition in New York (1926). From the Left: Captain Adam Królikiewicz, Major Michat Toczek, Lieutenant Kazimierz Szosland. Source: R. Urban, RidersOlympians of the Second Republic of Poland, Gorzów Wielkopolski, 2012. P. 189.

The abovementioned G. Rau also wrote about the rightness of Polish trainers' actions, claiming that the horse should be trained in the riding arena, but also in the field and in this process a compromise between the

\footnotetext{
${ }^{3}$ The schedle of the Polish Army Championships included: dressage, mastery of melee weapon and firearms, an equestrian competition, a long distance run $(55 \mathrm{~km})$, and steeple chase. In contrast, the Polish Equestrian Championships also included in its schedule dressage and show jumping and eventing competition.
} 
old manege and natural systems is essential. He also pointed to the individual predispositions of the horse, as well as its comprehensive gymnastics [13]. The opinion about the existence of the Polish horse-riding school formulated, among others, by A. Królikiewicz was shared by many other horse and riding experts, among them Wojciech Pruski, who wrote: «it should be held that in Poland in 1924-1939 a native variety of the natural Italian horse-riding school was established and the main focus where it developed and from where it spread throughout the country was the CWK in Grudziądz». [10] Like any «novelty» - so was the Polish newly created horse-riding school - that forced some changes. Except the entire organizational and training sphere, it also concerned the construction of the horse tack $[4,17]^{4}$, mainly saddles that were adapted to new requirements. As a result of cooperation of leading riders and craftsmen, in 1925 another model was introduced to the military horse units, so-called Polish military horse tack model 25 [17]. The changes also took place in the sports-type tack and mainly they came down to the rider's position that was closer to the horseback, as well as reduction of rider's weight.

Since dealing with horses is the art, it is not advisable to hold on to one «school» slavishly. In sports career, but also in breeding, you can encounter a horse when it is not suitable for it. Therefore, wellunderstood openness and the ability to follow new, unpaved trails are recommended here. It is especially useful when already known solutions do not yield the desired effect. In recent times, the Italian Captain Federico Caprilli first noticed this, thus repaying great favors to the equestrian sport. Captain of the 2nd Cavalry Regiment Jarosław Suchorski, like Caprilli, stated that: «Each horse during training and performance (contests - author's complement) should be treated individually. Every training should develop and strengthen the horse». It is no coincidence that Polish horse-riding in the interwar period has triumphed at many hippodromes in Europe and America.

The Summary. Forming the Polish Army at the beginning of the 20th century, taking advantage of the tangle of favorable political circumstances, brought Poland a long-awaited independence. The Polish Legions appointed by the Supreme National Committee played an invaluable role in this process. The soldiers of this formation were characterized by unusual honor and deep patriotism. As it turns out today, this phenomenon was particularly visible among the lancers forming the 1st and 3rd Brigade. The horse at that time was the basic way for the rapid movement of troops and the equestrian sport emerged from the drill and cavalry practice successively. It needs be mentioned that its origins could be seen in the late nineteenth century [11]. At that time, the border between the horse military service and the sport was very smooth. It often happened that efficiency exercises of cavalry units reflected sports competitions in today's understanding and in other cases the sport competitions resembled cavalry training [19]. In Germany, the relationship between horse breeding and horsemanship, which to a large extent correlated with cavalry training, was noticeable very early. For the above reasons, officers were required to participate in races and hunting race in East Prussia [8].

In the reborn Republic of Poland, however, the Central Horse-Riding School was already established in 1920, renamed a bit later to the Cavalry Training Center (1928). Throughout the school's existence, a section functioned within its structure, whose officers were responsible not only for training and improving horseriding skills, but also for preparing for equestrian competitions [18]. Horse artillery adopted almost identical solutions.

It should be mentioned that a large number of these animals was also in the service of the Border Protection Corps. Horse-riding training was at that time a component of the general military training. That is why since 1923 horse competitions for the Polish Army Championships were held. Officers of the Second Republic of Poland were even the first on the European continent to initiate the competition in the Equestrian Polish Championships [1]. Thus, proper mastery of the art of horse riding was necessary in military activities and sport competitions. That is why Polish officers developed their own style, also called the Polish horseriding school. Its significance was highlighted forcefully during the VIII, IX and XI Summer Olympic Games. Then, the representation of the Second Republic of Poland gained medals and fame invaluable to the reviving state.

\section{References}

Archival sources and publications

1. The Archive of the Olsztyn Sports Museum, Program of the XXIV Equestrian Polish Championships.

\footnotetext{
${ }^{4}$ The horse tack is a set of equipment used for horseback riding and for leading a horse. It consists of, among others: a saddle with stirrups, a bridle consisting of a bit and a halter, as well as reins, a breastplate and a crupper. (See R. Wagner, op. cit., p. 8; T. Andrzejewski. To understand the horse, Gniezno, 2001, p. 103).
} 
2. The Central Military Archives, Inventory of Military Schools, p. 41.

3. The Central Military Archives, Inventory of Military Schools, Statute of the Central Camp of Artillery NCOs, p. 1.

4. Andrzejewski, T. (2001). To Understand the horse. Pallottinum Printing House.

5. Hubiak, P. (2003). Belina and his lancers. The Foundation Documentation Centre of the Independence Action.

6. Królikiewicz, A. (1957). Yesterday, today and tomorrow of the Polish horsemanship. RW LZS Publishing Company Łódź.

7. Leżeński, C. (1978). Only horseshoes marks left. Book and Knowledge.

8. Pruchniewicz, W. (2003). Horse-riding Academy. Equestrian Academy.

9. Przyboś, A., Żelewski, R. (1959). Diplomats of former times. Old Polish accounts from the 16th and 17th centuries. $W L$.

10. Pruski, W. (1982). The history of equestrian competitions in Poland. Sport and Tourism.

11. Pruski, W. Grabowski, J., Schuch, S. (2006). Horse breeding. T. I. PWRiL.

12. Rau, G. (1929). The riders battle for the Olimpic Games of 1912, 1920, 1924 and 1928. Schickhardt \& Ebner.

13. Rau, G. (1937). The World's Horsemanship at the Olympic Games of 1936. Saint Georg.

14. Romaszkan, G. (1923). Is there a compromise between the old and the new horse-riding school possible? Rider and Breeder, 44, 357-359.

15. Sawicka, Z. (2001). The horse in the life of nobility in the $16^{\text {th }}-18^{\text {th }}$ centuries. Adam Marszatek.

16. Urbankiewicz, J. (1996). Polish horse-riding legend. W. Grochowalski.

17. Wagner, R. (1986). The influence of horse riding schools on building of horse tack in Poland. National Scientific Publishing House.

18. Urban, R. (2003). Development of horse-riding sport in Poland between years 1918 and 1939. The Academy of Physical Education.

19. Wójcik, Z. (2010). Equestrian sport in Warmia and Mazury region in the years 1945-1975. ERZET.

20. Wójcik, Z. (2011). Leading schools and systems of horse riding in Europe (1550-1920). Academic Yearbooks of the College of Physical Education and Tourism, 7, 102-104.

21. Wójcik, Z. (2020). Italian horse riding school. Physical education, sport and health culture in modern society. Lutsk, Ukraine, 1, 60-63.

Стаття надійшла до редакції 31.03.2020 p. 